\title{
Characterization of Fine Fractions from the Processing of Municipal Solid Waste Incinerator Bottom Ashes for the Potential Recovery of Valuable Metals
}

\author{
Sebastian Keber ${ }^{1, *(\mathbb{D}}$, Thomas Schirmer ${ }^{2}$, Tobias Elwert ${ }^{3}\left[\right.$ and Daniel Goldmann $^{1}$ \\ 1 Department of Mineral and Waste Processing, Institute of Mineral and Waste Processing, Waste Disposal \\ and Geomechanics, Clausthal University of Technology, Walther-Nernst-Str. 9, 38678 Clausthal-Zellerfeld, \\ Germany; daniel.goldmann@tu-clausthal.de \\ 2 Department of Mineralogy, Geochemistry, Salt Deposits, Institute of Disposal Research, Clausthal University \\ of Technology, Adolph-Roemer-Str. 2A, 38678 Clausthal-Zellerfeld, Germany; \\ thomas.schirmer@tu-clausthal.de \\ 3 New Energy Vehicle Research Center, Qingdao University, Ningxia Road No. 308, Qingdao 266071, China; \\ elwert@elwert-consulting.com \\ * Correspondence: sebastian.keber@tu-clausthal.de; Tel.: +49-5323-72-2135
}

Received: 20 July 2020; Accepted: 21 September 2020; Published: 23 September 2020

\begin{abstract}
Municipal waste incinerator bottom ashes contain copper contents comparable to those of low-grade ores in addition to other valuable metals. While the processing of coarse fractions $(>2 \mathrm{~mm})$ is state of the art, the fines with their residual metal content are landfilled. This paper presents the results from a mineralogical characterization of fine fractions from the processing of municipal solid waste incinerator bottom ashes. From the results, possible approaches for a recovery of copper from the fine fraction are derived. Spatially resolved phase analysis reveals that the material contains a very heterogenic mixture of naturally occurring compounds as well as particles of alloys, metals, artificial oxides, and sulfides. The most interesting element to recover is copper. Copper can be found in the form of alloys, simple sulfides (XS), and oxides (XO). During the incineration process, new phases are generated that differ from natural ones and therefore can be called artificial minerals. Additionally, several components are partially altered due to oxidation, especially after the prolonged outside storage of the bottom ash. Crystalline silicate and glass particles are only sporadically enriched in $\mathrm{Cu}$. Based on these results, different processing techniques are discussed. Due to the small particle size distribution and the physical and physico-chemical properties of the particles, flotation seems to be the most promising technique for the enrichment of copper from municipal solid waste incineration bottom ash (MSWI-BA) fine fractions.
\end{abstract}

Keywords: waste incineration; bottom ash; flotation; copper; mineral characterization; municipal waste incineration bottom ash; artificial minerals

\section{Introduction}

In the context of current efforts in the field of resource and energy efficiency, waste streams and deposits with fine-grained metals are getting increasing attention. The reason for this is that reduction in environmental impact is driving recycling, as well as the potential to produce metal concentrates through recycling at lower costs than those of production from primary sources [1].

While the processes to produce metals from coarse materials from secondary sources are widely investigated and already state of the art, the processing of fine-grained materials before further treatment by hydro- and pyrometallurgical processes requires further research. Additionally, only a 
limited number of suitable processing techniques are available [2]. In particular, metals from waste streams with low metal contents are getting lost for this reason.

While the mineral phases of primary resources are well known and have been investigated for many decades, the mineral phases of waste streams have not been entirely identified yet. Depending on their origin and occurring transformation processes, these phases include metals, alloys, and metal compounds that often have no natural equivalent. Therefore, they are called artificial metal/mineral phases [3-7]. Examples of waste streams and residues which can contain those artificial phases are:

(1) Slags and dusts from metallurgical processes [8-10];

(2) Ashes and dusts from incineration plants [3,11,12];

(3) Dusts from the mechanical processing of waste electrical and electronic equipment (WEEE) [13];

(4) Sludges from hydrometallurgical processes [14];

(5) Sludges from metalworking processes [15].

The recycling rate of metals from fine-grained waste streams depends strongly on their complexity and the prices for the contained metals. Examples of waste streams with high recycling rates in industrial processes are zinc and iron-containing dust from the steel industry, copper-containing slags, and dust from nonferrous metallurgical plants, as well as precious metal-containing dust from WEEE recycling. In contrast to that, recycling rates for waste streams with low metal contents or a very high complexity are substantially lower. Examples of such waste streams are metallurgical slags with low residual contents of metals, leaching residues from hydrometallurgical processes, and fine fractions from the processing of municipal solid waste incineration bottom ash (MSWI-BA) [16].

A current research project at the Clausthal University of Technology uses the MSWI-BA as an example to investigate the processing of artificial metal phases. The first working package in this project is the mineral characterization of MSWI-BA. For this purpose, several samples of fine fractions from MSWI-BA have been investigated. The results are presented in this paper. A particular focus is laid on the investigation of the microstructures and surfaces of particles.

\subsection{Municipal Solid Waste Incineration}

In the European Union (EU), around $245 \mathrm{Mt}$ of municipal solid waste (MSW) is produced per year. Germany alone has a share of approximately $50 \mathrm{Mt}$ per year. In the EU, 26\% of the MSW undergoes waste incineration. The main goals of incineration are the destruction of (hazardous) organic substances, volume reduction, and the recovery of energy [17].

Table 1 shows the typical content of selected elements for MSW in Germany. It shows high variations for the single elements. Element concentrations depend on the region and neighborhood, but also variations over time are observed. Besides potential hazardous elements such as lead or cadmium, MSW also contains elements of economic interest like copper or zinc.

Table 1. Typical content of selected elements for MSW in Germany (DS = dry substance) [17].

\begin{tabular}{ccc}
\hline Element & Unit & Content \\
\hline Carbon & $\%$ DS & $18-40$ \\
Oxygen & $\%$ DS & $15-22$ \\
Sulfur & $\%$ DS & $0.1-0.5$ \\
Lead & ppm DS & $100-2000$ \\
Cadmium & ppm DS & $1-15$ \\
Copper & ppm DS & $200-700$ \\
Zinc & ppm DS & $400-1400$ \\
Nickel & ppm DS & $30-50$ \\
Carbon & $\%$ DS & $18-40$ \\
\hline
\end{tabular}

In the EU, the number of installed MSW incineration plants is about 470 . Around $90 \%$ of the input is processed in incineration plants with air-cooled grates. The primary air is injected through the grate, 
while secondary air is injected into the incineration chamber. To achieve a good burnout in the gas phase and to destroy hazardous compounds, a temperature of $850^{\circ} \mathrm{C}$ for the flue gas for at least $2 \mathrm{~s}$ is required by law [18]. The primary indicator of the quality of incineration is the carbon monoxide content in the flue gas. In most plants, only the temperature of the flue gas is measured. The actual incineration temperature on the grate itself is not controlled [17].

After incineration, the bottom ash is cooled down and discharged. The most common type of discharger uses a waterbed. The discharger also seals the furnace from the outer atmosphere. In recent years, a new dry discharger system has been employed in newer plants in Switzerland $[17,19]$.

\subsection{Municipal Waste Incineration Bottom Ash}

The term "bottom ash" (MSWI-BA) describes a mixture of unburned materials, ashes as a product of incineration, and slag and metal particles that have undergone a melting process. Besides that, chemical reactions lead to further phases such as sulfides. Due to the fast incineration process, the occurring compounds are not in a thermodynamic equilibrium and are partly of non-stoichiometric composition. That often leads to difficulties in describing the particles in terms of adequately specified phases. Nevertheless, the components of MSWI-BA can be classified into different phase groups (e.g., [20]). The matrix consists of amorphous compounds (slag, glass), silicates, quartz, calciumand calciumalumosilicates, feldspar $(\mathrm{K}, \mathrm{Na})$, calcite, anhydrite, halides $(\mathrm{K}, \mathrm{Na})$, and iron oxides (magnetite, hematite) [21]. Seifert et al. additionally list melilith, clinopyroxene, wollastonite, wuestite, and monticellite in the melt products [22].

Depending on the waste sources or regions of collection of MSW, the composition of MSWI-BA is highly variable. The material often contains significant amounts of valuable (e.g., $\mathrm{Cu}$ ) and also environmentally relevant elements ( $\mathrm{As}, \mathrm{Pb}, \mathrm{Cd}, \mathrm{Cr}, \mathrm{Hg}$, and others) [23]. Furthermore, the ash contains iron and ferrous alloys ( $\mathrm{Fe}, \mathrm{Co}, \mathrm{Ni})$ and aluminum, as well as other nonferrous metals (e.g., $\mathrm{Zn}$ ) and their oxides and sulfides. According to [20], the average composition of MSWI-BA is:

(1) Mineral fraction (coarse): 32\%;

(2) Grit < $2 \mathrm{~mm}$, slag: $27 \%$ each;

(3) Metals: $11 \%$;

(4) Organics: $3 \%$.

The mineral compounds in MSWI-BA are unstable against weathering when deposited outside, especially when in contact with moisture. Depending on alteration (water contact), hydrated compounds such as Friedel's salt, ettringite, hydrocalumite, and rosenhahnite will form [24]. Additionally, the metals-especially $\mathrm{Cu}$-will be subject to oxidation and thermal alteration unless the surface is covered with a protective oxide layer (e.g., in the case of $\mathrm{Cr}$ ) [20].

\subsection{Processing-State of the Art}

The industrial processing of MSWI-BA typically includes screening, crushing, sifting, manual sorting, and magnetic and eddy current separation to recover valuable metals and produce defined mineral products. While the applied unit operations are similar, the exact flowchart of each processing plant may vary. Due to technical, economic, and physical limitations, typically, processing down to a lower particle size of $2 \mathrm{~mm}$ is industrially realized. Recent developments in eddy current separation may allow dry processing down to $0.5 \mathrm{~mm}$ in the near future. Wet processes enable processing down two $63 \mu \mathrm{m}$, but this procedure requires special incineration technologies-e.g., dry discharging or the direct processing of the ashes $[17,19,25,26]$.

Another approach is to add a second process after the conventional processing route optimized for particles below $2 \mathrm{~mm}$. One of these is the RENE-Adapt (RENE: Recycling von Nichteisenmetallen (recycling of nonferrous metals))) process developed at Clausthal University of Technology. It is based on a novel technology of eddy current separation and selective crushing in combination with sorting by screening. The process is described in Section 2.1. A major drawback of the RENE-Adapt process is 
the production of high amounts of wet fine-grained residues with a particle size below $160 \mu \mathrm{m}$ which still contain relevant metal contents and are difficult to landfill [16,27].

Despite such efforts, most attempts come to their limits when the valuable elements are not present in their metallic form but appear in compounds such as oxides or sulfides. These phases may occur mainly in the fine fraction of the MSWI-BA. For such materials, other processing techniques such as flotation might be applied. While flotation is widely used in the processing of primary resources, its application in waste processing has not been established yet, with few exceptions.

Earlier investigations showed the general applicability to produce a copper concentrate by flotation from fine fractions of MSWI-BA. Nevertheless, it was not possible to reach a sufficiently high copper concentration for further metallurgical processing at a reasonable recovery rate [27].

\section{Materials and Methods}

\subsection{Material}

The MSWI-BA analyzed and characterized in this study originates from a processing plant in Halle/Döllnitz (Germany). The plant processes ashes from several municipal waste incineration plants, as well as from refuse-derived fuel incineration plants. The plants are mostly located in the southern and eastern parts of Germany. The ashes are stored for drying and carbonization for several weeks. In this time, they are mixed so that the homogenized material cannot be assigned to a specific incineration plant.

For this study, two samples from the fraction below $2 \mathrm{~mm}$ were taken. The first sample originates directly from the processing plant, while the second underwent outside storage for several months. A total of $1.2 \mathrm{t}$ were collected from each material and split for further processing. About one year later, a third sample was taken directly from the processing plant to verify the results and investigate the variations over time. The first two samples were chosen to investigate the effects of weathering.

For the chemical and microprobe analysis, three samples without further processing were prepared by sample division and sieving at $160 \mu \mathrm{m}$. Additionally, the first two samples were processed with the RENE-Adapt process, comprising the following steps:

(1) Dry mechanical processing to separate coarse material;

(2) Wet mechanical processing to separate finer metal particles;

(3) Hydrometallurgical processing to recover the residual metal content.

For the work presented in this paper, only the first two steps were carried out. The flowchart of these two steps is shown in Figure 1. The dry mechanical processing starts with a screening at $0.5 \mathrm{~mm}$. The fine fraction $(<0.5 \mathrm{~mm})$ is directly processed in a wet mechanical process step. The coarse material $(>0.5 \mathrm{~mm})$ is milled with a roller mill. After that, a second screening at $0.5 \mathrm{~mm}$ is carried out. The coarse material is then processed by magnetic and eddy current separation to obtain a magnetic and non-magnetic fraction for further processing and a nonferrous product. The residuals are forwarded to the wet mechanical process [16,27].

The wet mechanical process is based on selective milling with subsequent sorting by screening. The material is milled in a rod mill. The screening is carried out at $160 \mu \mathrm{m}$. While native metals are enriched in the coarse fraction in the form of rolled-out particles, the brittle mineral phases pass the screen. The wet mechanical process is carried out in three individual process lines-one for each residue of the dry mechanical process $[16,27]$. From the RENE-Adapt process, three additional samples $<160 \mu \mathrm{m}$, representing the three process lines, are collected for the investigations (see Figure 1). These samples were chosen to determine differences in the process lines.

Table 2 gives an overview of all the investigated samples. 


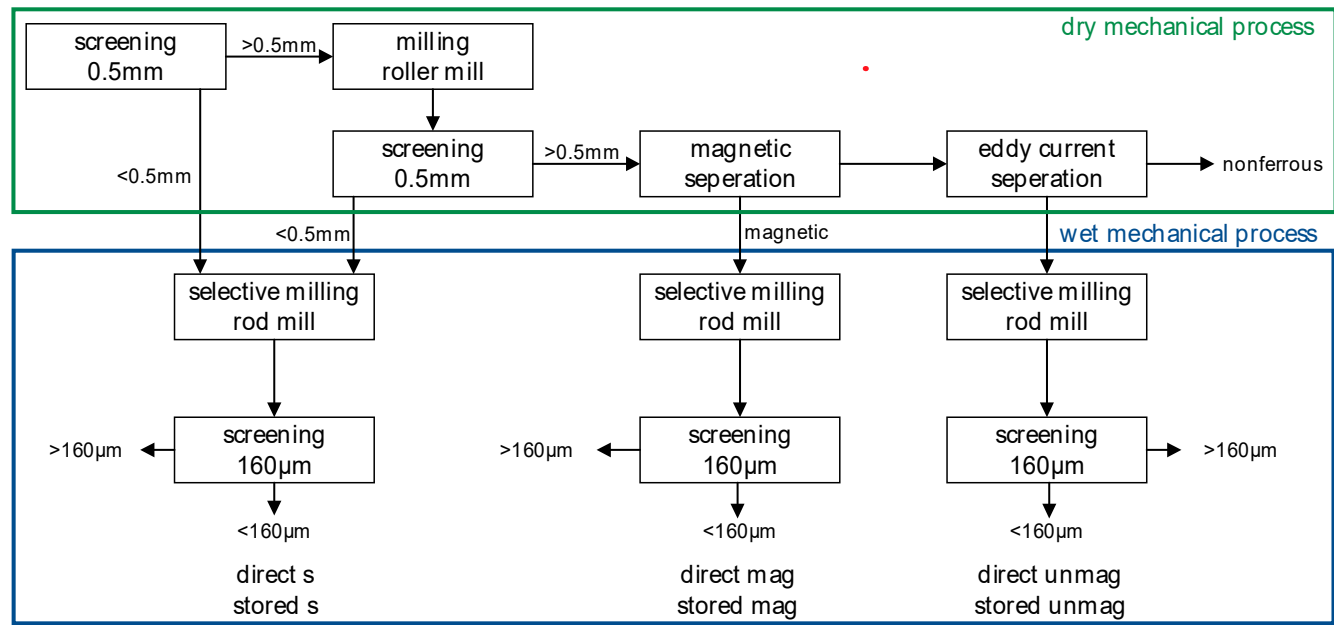

Figure 1. Flowchart of the mechanical stages of the RENE-Adapt process with sample names. An explanation of the sample names is given in Table 2.

Table 2. Overview of the investigated samples.

\begin{tabular}{ccc}
\hline Sample & Origin & Preparation \\
\hline $\begin{array}{c}\text { Direct unp } \\
\text { Stored unp } \\
\text { Validation unp }\end{array}$ & $\begin{array}{c}\text { direct from the processing plant } \\
\text { from the storage area } \\
\text { direct from the processing plant }\end{array}$ & $\begin{array}{c}\text { Sample division and screening at } \\
160 \mu \mathrm{m} .\end{array}$ \\
\hline $\begin{array}{c}\text { Direct } \mathrm{s} \\
\text { Direct mag }\end{array}$ & direct from the processing plant & $\begin{array}{c}\text { Sample division and processing } \\
\text { with the RENE-adapt process. }\end{array}$ \\
Direct nomag & & Sample division and processing \\
$\begin{array}{c}\text { Stored s } \\
\text { Stored mag }\end{array}$ & from the storage area & with the RENE-adapt process. \\
\hline Stored nomag & &
\end{tabular}

\subsection{Analytical Methods}

To determine the bulk chemistry, the samples were fused with $\mathrm{Li}_{2} \mathrm{~B}_{4} \mathrm{O}_{7}$ for $20 \mathrm{~min}$ at $1050{ }^{\circ} \mathrm{C}$, followed by microwave-assisted aqua regia dissolution. The resulting solution was analyzed with inductively coupled plasma optical emission spectrometry (ICP-OES) using an Agilent 5100 system, (Agilent, Santa Clara, CA, USA).

The bulk phase determination was carried out with powder X-ray diffraction (PXRD) using a Panalytical X'Pert 3020 Powder diffractometer (Malvern Panalytical B.V., Lelyweg 1, 7602 EA Almelo, The Netherlands) equipped with a $\mathrm{Cu}$ X-ray tube (Malvern Panalytical B.V., Lelyweg 1, 7602 EA Almelo, The Netherlands).

To carry out the spatially resolved particle measurements and backscattered electron micrographs with Z-contrast (BSE(Z)), a Cameca SXFIVE FE (field emission) electron probe (Cameca, 29 Quai des Gresillons, 92230 Gennevilliers, France) equipped with 5 wavelength dispersive (WDX) spectrometers (Cameca, 29 Quai des Gresillons, 92230 Gennevilliers, France) was used. For optimal detection sensitivity, the acceleration voltage was set to $15 \mathrm{kV}$ at $40 \mathrm{nA}$. The elements were analyzed using appropriate characteristic K- and L-lines. To calibrate the wavelength dispersive $\mathrm{X}$-ray fluorescence spectrometers (WDRFA), a suitable selection of reference materials was used. Electron probe micro analysis EPMA (Eletron probe microanalysis) usually uses one-point calibration. The samples were prepared as polished blocks in epoxy resin and coated with carbon.

The particle size distributions of the fine fractions were measured with laser diffraction in suspension using a Sympatec Helos/KR (Sympatec GmbH, Clausthal-Zellerfeld, Germany) with Quixel disperser (Sympatec GmbH, Clausthal-Zellerfeld, Germany). 


\section{Results}

\subsection{Particle Size Distribution}

All the samples show similar particle size distributions. The particle size distributions of sample "direct unp" and sample "direct nomag" are shown exemplarily in Figure 2. Sample "direct nomag" comprises a slightly higher share of fine particle sizes due to the additional processing. The $x_{90}$ values for the sample are 145 and $123 \mu \mathrm{m}$. With $22 \%$ and $30 \%$, both samples have a high amount of fines below $10 \mu \mathrm{m}$.

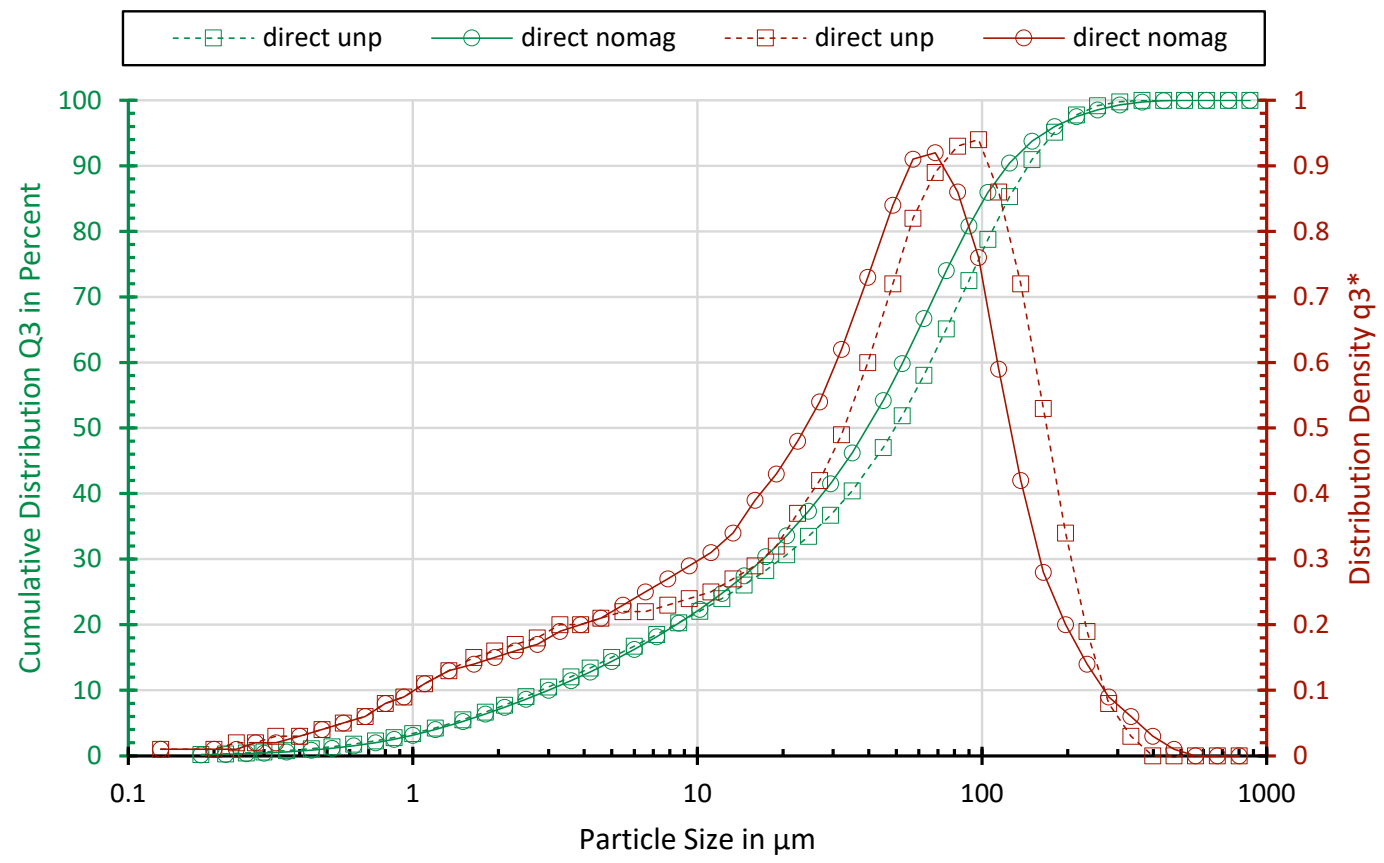

Figure 2. Particle size distribution of sample "direct unp" and sample "direct unp".

\subsection{Bulk Chemistry}

The contents of selected metals in the investigated fine fraction of MSWI-BA are presented in Table 3. The bulk chemical composition of the samples direct from the processing plant and the storage area show similar concentrations, albeit the stored MWI-BA is several months older and might originate from different incineration plants. The variation is much lower than expected from the literature. The comparison of the bulk chemical composition of the unprocessed and processed samples shows only moderate or no depletion of the most analyzed elements in the fine fraction. This is of particular interest, because the fraction below $160 \mu \mathrm{m}$ represents only a small part of $7-10 \%$ of the unprocessed material. In contrast, after applying the RENE-Adapt process, this fraction makes up for about $97 \%$ of the original material.

One exception from this is silver, which is significantly depleted by the RENE-adapt process, as seen in the sample "stored unp" in comparison with the processed samples. This indicates that most of the silver is bound to metallic copper, which is removed by eddy current separation or selective comminution. The primary source for silver is probably electric contact material from WEEE. The fact that no silver could be detected in the sample "stored mag" shows that there is no intergrowth between the silver and magnetic particles. The metal of highest economic interest is copper, with a concentration of about $0.3 \%$ in both the unprocessed and processed samples. This means that the copper concentration is comparable with that of low-grade copper ores.

Another metal of economic interest might be zinc. The zinc concentration is roughly twice as high as the amount of copper, which corresponds to the ratio of these elements in MSW (see Table 1). Two primary sources of metallic zinc in the MSWI-BA are possible, as an alloying element for brass or 
as corrosion protection of iron components (sheets, screws, etc.). Interestingly, this element shows no apparent correlation with copper or with iron. One explanation could be that the zinc is carried into the MSWI through the fine fraction of shredder residues, which are, in part, incinerated for disposal. Another source could be zinc from the surface of iron components, where coatings are oxidized during the incineration and then removed due to thermic stress through the wet discharger or mechanical friction during transportation. It is also possible that part of the zinc originates from zinc oxide, which is used as pigment in various products.

Despite being one year younger, the sample "Validation unp" shows no significant differences. This indicates that only low variations over time take place at the chosen processing plant.

Table 3. Contents of the selected elements in the investigated samples.

\begin{tabular}{ccccccccccc}
\hline Element & $\mathbf{A g}$ & $\mathbf{A l}$ & $\mathbf{C u}$ & $\mathbf{F e}$ & $\mathbf{N i}$ & $\mathbf{P b}$ & $\mathbf{S n}$ & $\mathbf{Z n}$ & $\mathbf{C a}$ & $\mathbf{S i}$ \\
\hline Unit & $\mathbf{p p m}$ & $\mathbf{\%}$ & $\mathbf{p p m}$ & $\mathbf{\%}$ & $\mathbf{p p m}$ & $\mathbf{p p m}$ & $\mathbf{p p m}$ & $\mathbf{p p m}$ & $\mathbf{\%}$ & $\mathbf{\%}$ \\
\hline Direct unp & n.a. & 3.58 & 3125 & 4.44 & 262 & 799 & 150 & 7788 & 14.25 & 8.64 \\
Stored unp & 573 & 4.03 & 2744 & 4.12 & 201 & 726 & n.a. & n.a. & 725.71 & n.a. \\
Validation unp & n.a. & n.a. & 2944 & 3.31 & n.a. & 1272 & n.a. & 9753 & 19.72 & 7.48 \\
Direct s & n.a. & 3.73 & 3510 & 5.94 & 579 & 877 & 165 & 6803 & 13.19 & 15.42 \\
Direct mag & n.a. & 3.99 & 2771 & 15.87 & 715 & 647 & 194 & 4214 & 12.52 & 14.86 \\
Direct nomag & n.a. & 3.79 & 2526 & 2.14 & 405 & 1249 & 195 & 4978 & 11.76 & 22.59 \\
Stored s & 22 & 4.23 & 2661 & 5.73 & 478 & 876 & n.a. & n.a. & 876.21 & n.a. \\
Stored mag & $<5$ & 4.01 & 2889 & 14.93 & 558 & 8823 & n.a. & n.a. & 8823.35 & n.a. \\
Stored nomag & 74 & 4.04 & 2604 & 2.37 & 331 & 4486 & n.a. & n.a. & 4486.14 & n.a. \\
\hline
\end{tabular}

n.a.: Not analyzed.

Figure 3 shows the concentration and cumulative content of copper, dependent on the particle size. While, in the classes above $20 \mu \mathrm{m}$, no significant relationship can be observed, the processed samples show a slight enrichment of 2 in the fraction below $20 \mu \mathrm{m}$. Probably, Cu is oxidized to a brittle mineral form such as copper oxide so that the selective crushing does not lead to deformation but the crushing of the copper. From the copper contained in the fraction below $100 \mu \mathrm{m}$, about $40 \%$ of the processed sample and nearly $60 \%$ of the processed sample lie below $20 \mu \mathrm{m}$.

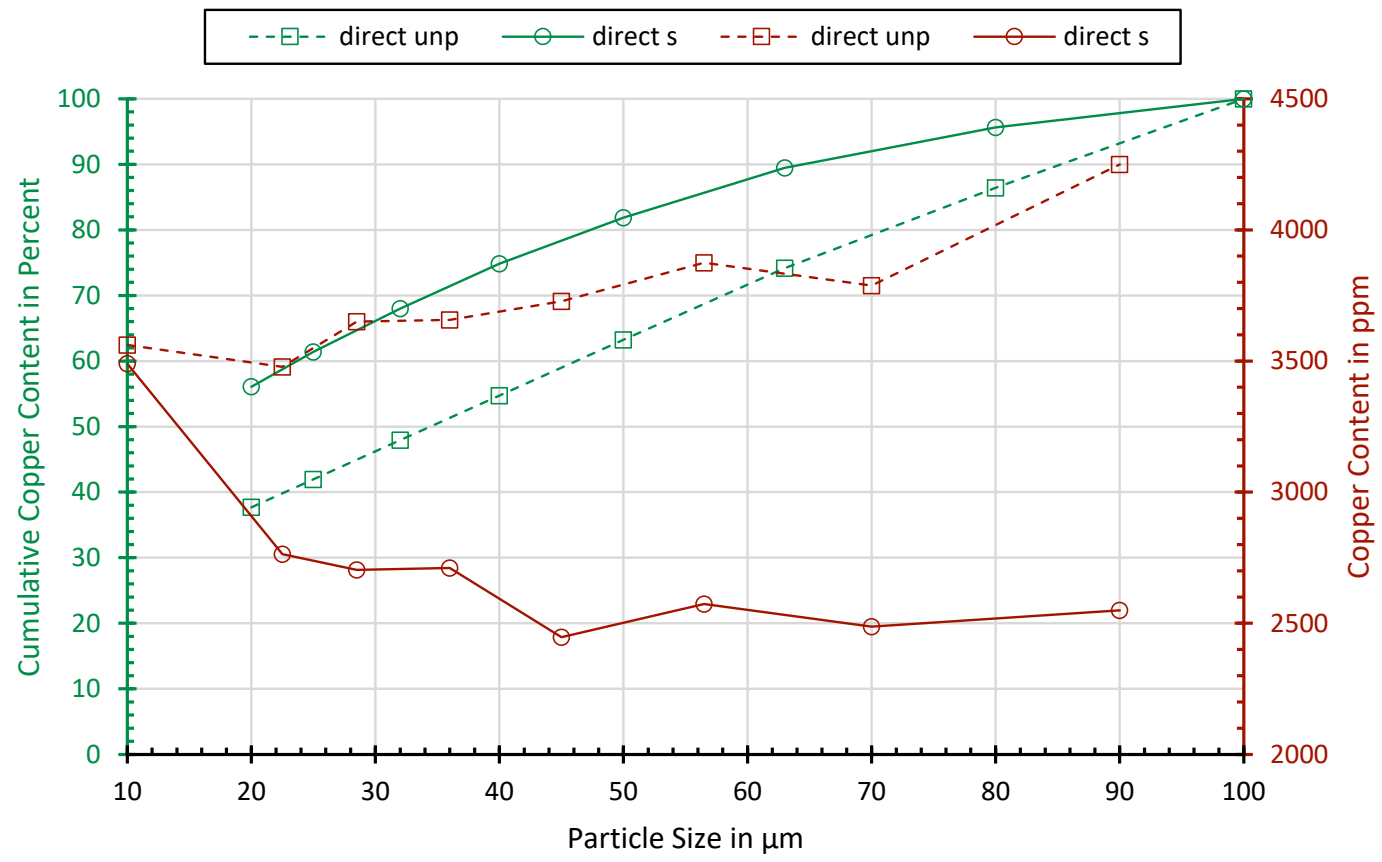

Figure 3. Copper concentrations and cumulated copper contents dependent on the particle size. 


\subsection{Bulk Phase Composition}

The XRD spectrum from the sample "direct unp" is shown in Figure 4. The main gangue phases are silica and calcium-containing compounds such as calcite, anhydrite, and gypsum. This corresponds also with the high contents of silicon and calcium (see Table 3). Copper and other metal phases cannot be detected due to their low concentrations.

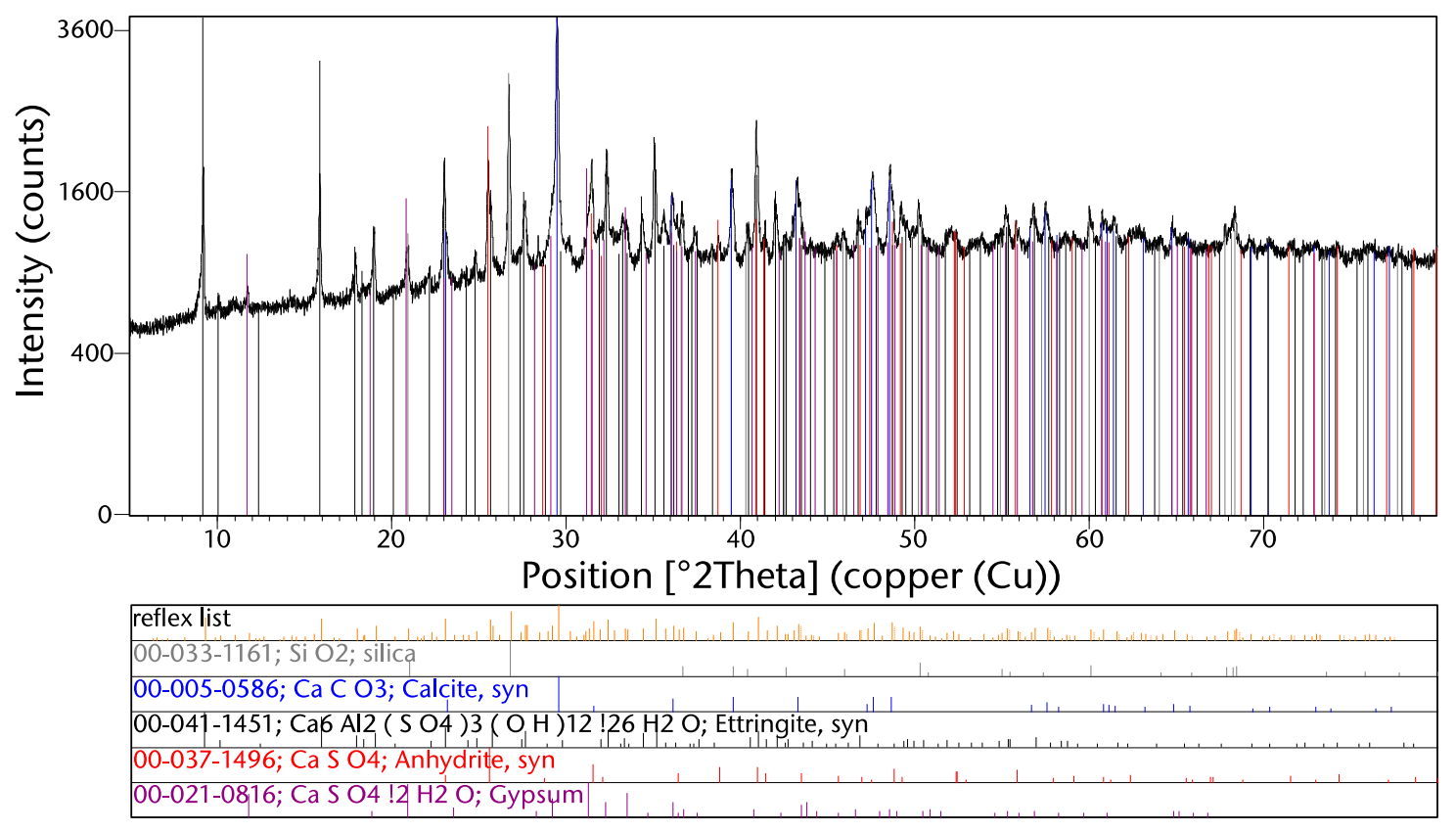

Figure 4. XRD spectrum of the sample "direct unp".

The formation of ettringite takes place during the hydration of cement. This, together with the presence of silica, calcite, anhydrite, and gypsum, leads to the assumption that at least a large share of this phase originates from used construction materials. Another main compound might also be glass, which cannot detected by the XRD due to its amorphous structure.

\subsection{Electron Imaging and Electron Probe Microanalysis}

\subsubsection{Overview}

The composition of the investigated MSWI-BA samples is very complex and can be divided into the following phase groups (Figure 5).

The exact ratios of the compounds cannot be determined with PXRD because of the high proportion of amorphous phases, leading to a high background in the diffractogram in combination with low peak intensities (see Figure 4). The elements are distributed over many different compounds with variable ranges of concentrations. Therefore, a balance on the basis of element concentrations cannot be calculated as well. 


\begin{tabular}{|c|c|c|c|c|c|c|c|c|c|}
\hline \multirow[b]{2}{*}{$\mathrm{Al}$} & \multicolumn{2}{|c|}{ Metal/Alloy Sulfides } & \multirow[t]{2}{*}{ Oxides } & \multirow[t]{2}{*}{ Glass } & \multirow{2}{*}{\begin{tabular}{|c|} 
Silicate \\
$\mathbf{x x}$
\end{tabular}} & \multirow[t]{2}{*}{ Sulfate } & \multirow[t]{2}{*}{ Carbonate } & \multirow[t]{2}{*}{ Phosphate } & \\
\hline & $x x x$ & & & & & & & & \\
\hline $\mathrm{Ca}$ & & & & & $x x$ & $x x$ & $x x$ & & \\
\hline Co & & & $x x$ & & & & & & \\
\hline $\mathrm{Cr}$ & $x x$ & & & & & & & & $375 \stackrel{1}{\square}$ \\
\hline $\mathrm{Cu}$ & $x x$ & $x x$ & $x x x$ & & & & & & \\
\hline Fe & $x x x$ & & $x x$ & & $x$ & & & & \\
\hline $\mathbf{K}$ & & & & & $x$ & & & & \\
\hline $\mathrm{Mg}$ & & & & & $x x$ & & $x$ & & \\
\hline Mn & & & $x x$ & & & & & & \\
\hline $\mathrm{Na}$ & & & & & $x$ & & & & \\
\hline $\mathrm{Ni}$ & $x x$ & $x x$ & & & & & & & og \\
\hline $\mathbf{P}$ & & & & & & & & $x x x$ & 12.5 윾 \\
\hline$S$ & & $\mathbf{x x x}$ & & & & $x x$ & & & $\div$ \\
\hline Si & $\mathbf{x X X}$ & & & & & & & & \\
\hline $\mathrm{Ti}$ & & & & & & & & & \\
\hline Zn & & & & & & & & & \\
\hline & $x x x, x x$ & ichme & of eleme & in pha & & & & & \\
\hline
\end{tabular}

Figure 5. Overview of the estimated abundance of the phase groups and element enrichments.

\subsubsection{Metals/Alloys}

This group comprises particles of metal splinters and melted droplets. The composition of these particles is highly variable and ranges from pure $\mathrm{Al}$, $\mathrm{Si}$ or $\mathrm{Fe}, \mathrm{Al} / \mathrm{Si}, \mathrm{Al} / \mathrm{Si} / \mathrm{Fe} / \mathrm{Cu}$ to ferroalloys (with $\mathrm{Mn}$, $\mathrm{Cr}, \mathrm{Fe}$ and $\mathrm{Ni}$ ) and $\mathrm{Sn}$ alloys (with $\mathrm{Cr}, \mathrm{Mn}, \mathrm{Fe}, \mathrm{Cu}$ ). In some cases, the particles contain rare elements such as lanthanides ( $\mathrm{La}, \mathrm{Pr}, \mathrm{Nd}), \mathrm{Nb}, \mathrm{Sb}, \mathrm{Ta}, \mathrm{W}$, and $\mathrm{Pb}$. The left electron micrograph in Figure 6 shows a complex mixture of compounds in an MSWI-BA with a matrix of alumosilicate, glass, oxides, sulfate, and metal particles. The morphology of the metal particle "Fe" in the left micrograph of Figure 6 indicates a molten droplet in contrast to the more splinter-like shape of the particle "CrMnFeNi." The right electron micrograph in Figure 6 shows a complex particle with $\mathrm{Pb}, \mathrm{Sn}, \mathrm{Cu}$, and $\mathrm{Fe}$. The inner region contains $\mathrm{Pb}$ and $\mathrm{Sn}$ mainly and is depleted in $\mathrm{O}$. At the rim of the particle, $\mathrm{Cu}$ is enriched and shows a stoichiometry between $\mathrm{CuO}$ and $\mathrm{Cu}_{2} \mathrm{O}$. The morphology of these particles shows a cauliflower-structure, with $\mathrm{Pb}$ - and $\mathrm{Sn}$-rich crystal whiskers running into the $\mathrm{Cu}$-oxide region.

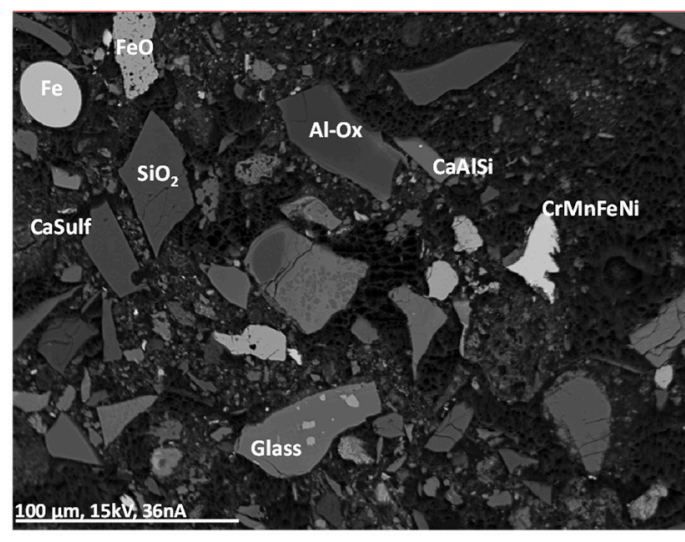

(a)

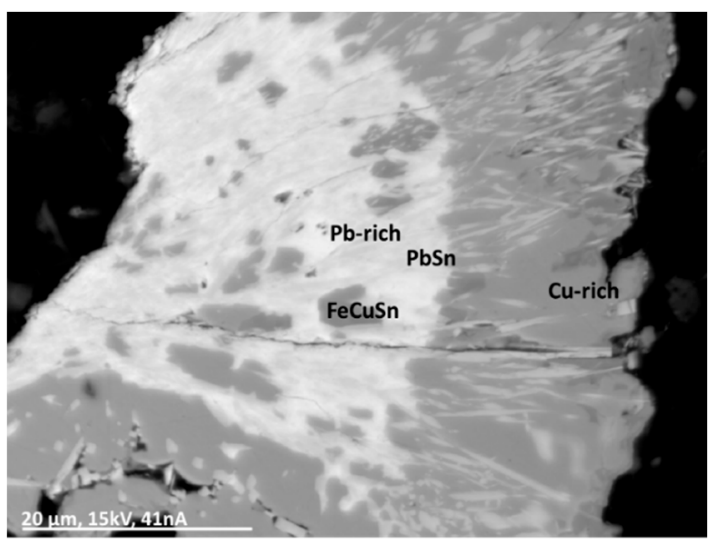

(b)

Figure 6. Backscattered electron micrographs (Z-contrast) (BSE(Z)) of a MSWI-BA sample. The material comprises of a complex mixture of different compounds. (a) Al-Ox: aluminum oxide with $\mathrm{Ca}, \mathrm{Fe}$, and $\mathrm{Zn}$; CaAlSi: calciumalumosilicate; CaSulf: agglomerate with calciumsulfate; CrMnFeNi: complex metal alloy; glass: siliceous glass with $\mathrm{Na}, \mathrm{Al}, \mathrm{Si}, \mathrm{P}, \mathrm{K}, \mathrm{Ca}$, Ti, and $\mathrm{Fe}$. (b) Pb-rich: region with $\mathrm{Pb}+$ $\mathrm{Al} / \mathrm{Si} / \mathrm{Cl} / \mathrm{Fe} / \mathrm{Cu} /(\mathrm{O}) ; \mathrm{PbSn}: \mathrm{PbSn}+\mathrm{Al} / \mathrm{Si} / \mathrm{Cl} / \mathrm{Fe} / \mathrm{Cu} /(\mathrm{O}) ; \mathrm{FeCuSn}$ : oxide with $\mathrm{Fe}, \mathrm{Cu}$, and Sn; Cu-rich: Cu oxide. 


\subsubsection{Sulfides}

This group comprises particles of compounds mostly with a simple XS stoichiometry, containing mainly $\mathrm{Cu}$ and Fe. The occurrence of pure $\mathrm{CuS}$ is not uncommon within this group. In some rare cases, the sulfides can be more complex with a bulk stoichiometry of $\mathrm{X}_{4} \mathrm{~S}_{3}$, probably as $\mathrm{Ni}_{3} \mathrm{~S}_{2} \cdot(\mathrm{Cu}, \mathrm{Fe}) \mathrm{S}$ containing $\mathrm{Fe}, \mathrm{Ni}$, and $\mathrm{Cu}$.

Particles can be monolithic with segregation lamellae or consist of a fine network of crystal whiskers (Figure 7), indicating fresh crystallizates. Thin oxide layers at the outer rim of particles show weathering processes (Figure 7a) (see Section 3.4.9).

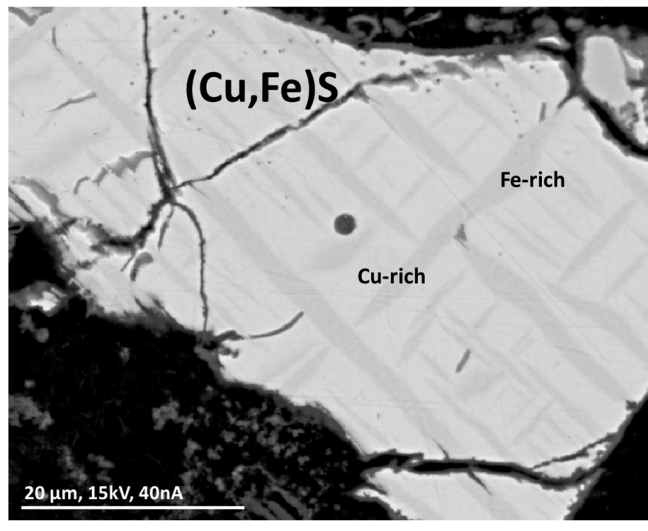

(a)

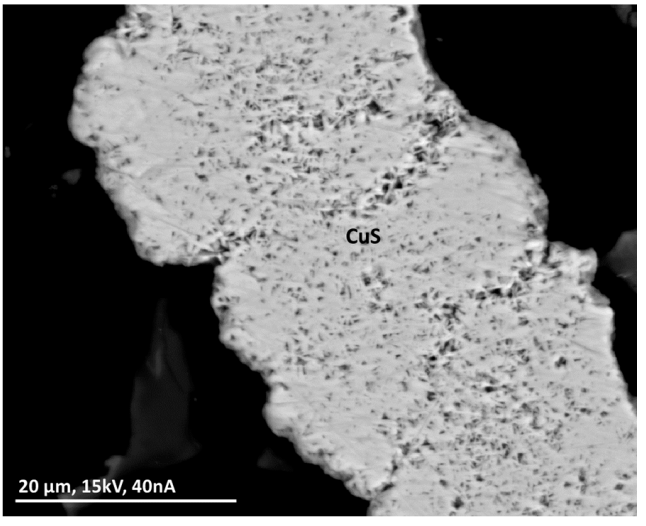

(b)

Figure 7. BSE(Z) micrographs of sulfide particles in a MSWI-BA sample. (a) Segregation lamellae of Fe-rich $(\mathrm{Cu}, \mathrm{Fe}) \mathrm{S}$ in $\mathrm{Cu}$-rich $(\mathrm{Cu}, \mathrm{Fe}) \mathrm{S}$ with an oxide layer on the outside. (b) Network of fine CuS-crystallites.

\subsubsection{Oxides}

This group comprises several different oxide types such as $\mathrm{XO}_{2}, \mathrm{XO}, \mathrm{XYO}_{3}, \mathrm{X}_{2} \mathrm{O}_{3}$, and $\mathrm{XYO}$, $\mathrm{SiO}_{2}$ being a primary compound of the matrix. In most cases, the metal oxide particles show a simple wuestite-like stoichiometry with $\mathrm{Fe}$ as a primary and $\mathrm{Al}, \mathrm{Ca}, \mathrm{Ti}, \mathrm{Mn}$, and $\mathrm{Zn}$ as minor compounds, sometimes as calciowuestite ((Fe, $\mathrm{Ca}) \mathrm{O})$. Mg-, $\mathrm{Mn-}, \mathrm{Co}-$, or $\mathrm{Zn}$-rich oxides of the type XO can be found in some particles. Additionally, in this group the occurrence of copper-rich compounds-in this case, $\mathrm{CuO}$ (partly with $\mathrm{Co}$ ) and $\mathrm{Cu}_{2} \mathrm{O}$-is not uncommon. Accessory oxide minerals are $\mathrm{Al}_{2} \mathrm{O}_{3}, \mathrm{TiO}_{2}$, $\mathrm{CaTiO}_{3}, \mathrm{FeTiO}_{3}$, and spinel. Additionally, oxides occur in the form of thin layering around metal or sulfide particles (see Figures 7 and 8).

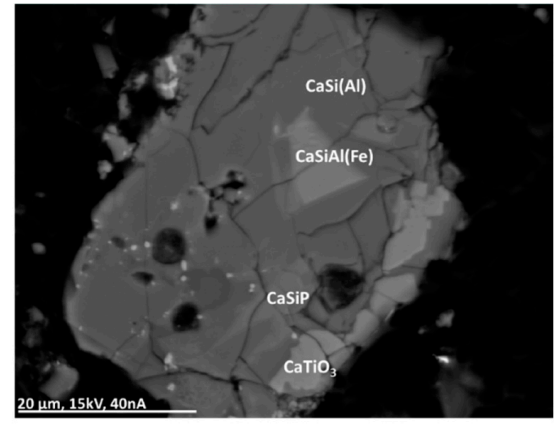

(a)

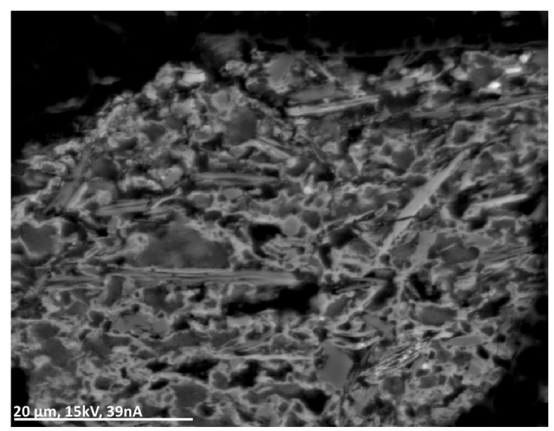

(b)

Figure 8. $\mathrm{BSE}(\mathrm{Z})$ micrographs of complex glass particles. (a) $\mathrm{CaSi}(\mathrm{Al})$ : calciumalumosilicate; $\mathrm{CaSiAl}(\mathrm{Fe})$ : calciumalumosilicate with $\mathrm{Fe}$ and $\mathrm{Ti}$; CaSiP: silicophosphate glass with $\mathrm{Cl}$, Ti, and Fe. (b) Complex glass particle with different $\mathrm{Mg}$-rich calciumalumosilicates with $\mathrm{S}$ and $\mathrm{K}$. Brighter regions additionally contain $\mathrm{Cu}$ and $\mathrm{Zn}$. 


\subsubsection{Glass and Silicates}

The main compound of the matrix is silicate glass, partly with a stoichiometric composition. The main essential elements are $\mathrm{Al}, \mathrm{Si}, \mathrm{Mg}, \mathrm{Ca}$, and Fe. The chemistry of this glass is highly variable (Figure 9) and can include noticeable concentrations of P. Additionally, some glass particles can contain $\mathrm{S}$ and $\mathrm{Cl}$, as well as $\mathrm{Ti}$ and $\mathrm{Mn}$. Furthermore, but rather infrequently, the concentration of $\mathrm{Cu}$ and $\mathrm{Zn}$ is elevated.

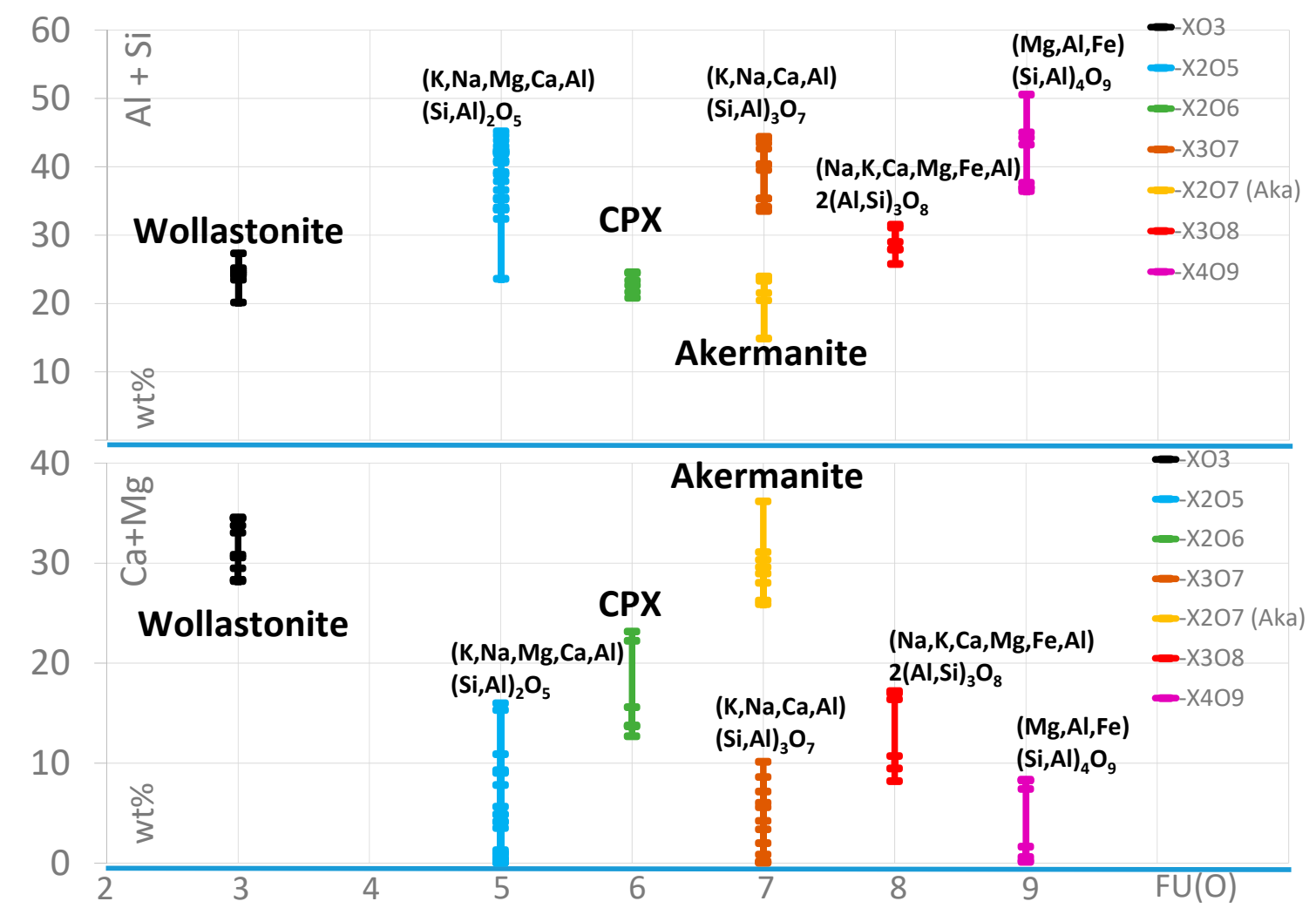

Figure 9. Element distribution of the selected main elements in different glass and silicates, listed concerning the oxygen formula units $(\mathrm{FU}(\mathrm{O}))$. CPX: clinopyroxene.

Besides $\mathrm{SiO}_{2}$, wollastonite, Ca-pyroxene (clinopyroxene), and an akermanite-like mineral can be distinguished.

\subsubsection{Carbonate, Phosphate, and Sulfate}

Compounds of this group are not common. In the analyzed samples, carbonates such as $\mathrm{CaCO}_{3}$ and $(\mathrm{Ca}, \mathrm{Mg}) \mathrm{CO}_{3}$ can be found. Besides the silicophosphate glass, $\mathrm{P}$ can be found in simple phosphates such as $\mathrm{Ca}_{3}\left(\mathrm{PO}_{4}\right)_{2}$. In some glass particles, $\mathrm{S}$ was found in the form of Ca-sulfate and, together with aluminum, in ettringite.

\subsubsection{Incorporation of Valuable Metals}

The only valuable metal to be frequently higher concentrated in the analyzed particles is $\mathrm{Cu}$. The highest concentrations of this metal can be found in sulfides and oxides (Table 4 , see corresponding Sections 3.4.3 and 3.4.4). However, the sulfides can be masked by an oxide layer (Figure 7). 
Table 4. Typical $\mathrm{Cu}$-containing oxide and sulfide compounds of the analyzed MSWI-BA samples. $\mathrm{O}$ *: stoichiometric balance.

\begin{tabular}{|c|c|c|c|c|c|c|c|c|c|}
\hline & $\mathrm{Cu}_{2} \mathrm{O}$ & $\mathrm{CuO}$ & $(\mathrm{Co}, \mathrm{Cu})_{2} \mathrm{O}$ & $(\mathrm{Cu}, \mathrm{Zn}) \mathrm{O}$ & $(\mathrm{Mg}, \mathrm{Fe}, \mathrm{Zn}) \mathrm{O}$ & $(\mathrm{Mn}, \mathrm{Fe}, \mathrm{Cr}, \mathrm{Ni}, \mathrm{Cu}, \mathrm{Zn})_{2}(\mathrm{Al}, \mathrm{Ti}, \mathrm{Fe}) \mathrm{O}_{4}$ & CuS & $(\mathrm{Cu}, \mathrm{Fe}) \mathrm{S}$ & Glass \\
\hline $\mathrm{Al}$ & 0.0 & 0.0 & 0.1 & 0.0 & 0.0 & 9.9 & 0.0 & 0.0 & 2.7 \\
\hline $\mathrm{Ca}$ & 0.2 & 0.4 & 0.1 & 0.1 & 0.1 & 0.2 & 0.1 & 0.3 & 26.9 \\
\hline $\mathrm{Co}$ & 0.0 & 0.0 & 71.9 & 0.0 & 0.1 & 0.0 & 0.0 & 0.1 & 0.0 \\
\hline $\mathrm{Cu}$ & 86.7 & 78.9 & 12.6 & 4.0 & 2.1 & 4.1 & 66.0 & 45.2 & 1.1 \\
\hline $\mathrm{Fe}$ & 0.2 & 0.5 & 0.2 & 0.3 & 51.9 & 12.2 & 0.9 & 22.5 & 2.8 \\
\hline $\mathrm{K}$ & 0.0 & 0.0 & 0.0 & 0.0 & 0.0 & 0.0 & 0.0 & 0.0 & 0.0 \\
\hline $\mathrm{Na}$ & 0.0 & 0.0 & 0.0 & 0.0 & 0.5 & 0.6 & 0.0 & 0.0 & 1.1 \\
\hline $\mathrm{Ni}$ & 0.0 & 0.0 & 0.1 & 0.0 & 0.1 & 7.9 & 0.0 & 0.2 & 0.1 \\
\hline $\mathrm{P}$ & 0.1 & 0.1 & 0.0 & 0.0 & 0.0 & 0.0 & 0.0 & 0.0 & 0.0 \\
\hline $\mathrm{S}$ & 0.3 & 0.0 & 0.2 & 0.0 & 0.0 & 0.0 & 31.0 & 31.2 & 0.0 \\
\hline $\mathrm{Si}$ & 0.0 & 0.3 & 0.1 & 0.0 & 0.0 & 1.4 & 0.0 & 0.1 & 19.3 \\
\hline
\end{tabular}

In some cases, the $\mathrm{Cu}$ concentration in glass particles is elevated (Table 4). Additionally, Cu occurs in metal splinters and alloys (Table 5).

Table 5. Typical Cu-containing low-oxygen compounds of the analyzed MSWI-BA samples.

\begin{tabular}{ccccccccccccc}
\hline & \multicolumn{3}{c}{ Ferroalloy } & \multicolumn{4}{c}{ Al-Ferroalloy } & \multicolumn{3}{c}{ Zn-Al-Alloy } & \multicolumn{2}{c}{ Si/Al-Si-Alloy } \\
\hline $\mathrm{Al}$ & 0.0 & 0.0 & 0.0 & 0.0 & 36.2 & 50.0 & 64.4 & 22.5 & 65.6 & 0.4 & 72.0 & 76.4 \\
$\mathrm{Ca}$ & 0.2 & 0.1 & 0.1 & 0.3 & 0.1 & 0.1 & 0.0 & 0.2 & 0.2 & 0.1 & 0.1 & 0.2 \\
$\mathrm{Co}$ & 0.1 & 0.1 & 0.1 & 0.3 & 0.0 & 0.1 & 0.0 & 0.1 & 0.0 & 0.0 & 0.0 & 0.0 \\
$\mathrm{Cr}$ & 0.0 & 0.3 & 0.0 & 0.0 & 0.0 & 0.0 & 0.3 & 0.1 & 0.0 & 0.0 & 0.0 & 0.0 \\
$\mathrm{Cu}$ & 23.1 & 4.7 & 1.8 & 1.6 & 36.9 & 14.4 & 3.7 & 1.7 & 1.9 & 27.4 & 3.7 & 1.3 \\
$\mathrm{Fe}$ & 40.9 & 41.9 & 58.7 & 60.9 & 17.9 & 27.0 & 22.6 & 64.5 & 0.1 & 0.9 & 2.9 & 0.2 \\
$\mathrm{~K}$ & 0.0 & 0.0 & 0.0 & 0.0 & 0.0 & 0.0 & 0.0 & 0.0 & 0.0 & 0.0 & 0.0 & 0.0 \\
$\mathrm{Mg}$ & 0.0 & 0.0 & 0.0 & 0.0 & 0.0 & 0.0 & 0.0 & 0.0 & 0.5 & 1.5 & 0.1 & 0.2 \\
$\mathrm{Mn}$ & 0.0 & 1.5 & 0.1 & 0.4 & 0.2 & 0.0 & 0.1 & 0.4 & 0.0 & 0.0 & 0.2 & 0.0 \\
$\mathrm{Na}$ & 0.0 & 0.0 & 0.0 & 0.0 & 0.0 & 0.0 & 0.0 & 0.0 & 0.7 & 0.1 & 0.0 & 0.1 \\
$\mathrm{Ni}$ & 0.5 & 0.1 & 0.1 & 0.3 & 0.5 & 0.8 & 0.1 & 0.1 & 0.0 & 0.0 & 0.0 & 0.0 \\
$\mathrm{P}$ & 0.0 & 0.8 & 0.0 & 0.0 & 0.0 & 0.0 & 0.0 & 0.0 & 0.0 & 0.2 & 0.0 & 0.0 \\
$\mathrm{~S}$ & 34.3 & 0.0 & 36.3 & 37.3 & 0.0 & 0.0 & 0.0 & 0.0 & 0.0 & 0.0 & 0.0 & 0.0 \\
$\mathrm{Si}$ & 0.0 & 42.1 & 0.0 & 0.0 & 5.9 & 2.9 & 3.6 & 10.3 & 0.6 & 64.7 & 18.4 & 18.3 \\
$\mathrm{Ti}$ & 0.0 & 5.6 & 0.0 & 0.0 & 0.0 & 0.0 & 0.0 & 0.1 & 0.0 & 0.1 & 0.2 & 0.1 \\
$\mathrm{Zn}$ & 0.7 & 2.1 & 0.0 & 0.1 & 0.1 & 0.0 & 0.1 & 0.1 & 26.9 & 1.7 & 0.4 & 1.1 \\
$\mathrm{Sum}$ & 100.0 & 99.4 & 97.3 & 101.1 & 98.0 & 95.3 & 95.0 & 100.0 & 96.6 & 97.3 & 98.1 & 98.0 \\
\hline
\end{tabular}

\subsubsection{Metal Enrichment in Different Fractions}

The initial material containing all the different compounds described above was processed to separate the metal-containing fractions (see Section 2.1). Specific attention was given to the behavior of the Cu-rich particles. The non-magnetic fraction ("direct unmag") contains higher amounts of Siand Al-containing alloy particles. Additionally, the number of $\mathrm{Cu}$-containing sulfides, and especially $\mathrm{Cu}$-containing oxides, is elevated. In this fraction, a higher amount of various accessory oxides (see Section 3.4.4) can be observed.

In the magnetic fraction ("direct mag") ferroalloy and iron oxide particles are enriched. A sample from the separation at $<0.5 \mathrm{~mm}$ with a subsequent sieving step at $160 \mu \mathrm{m}$ after comminution with a rod mill ("direct s") contained ferroalloy and iron oxide particles but fewer Cu-sulfide and -oxide particles. Interestingly, the amount of carbonate particles in this sample is higher. 


\subsubsection{Alteration}

Alteration processes were investigated using material after outside storage for several months. The $\mathrm{Cu}$-rich sulfide particles show alteration at the rim and along cracks (see Figure 10a). Intense alteration occurs at the Al-alloy particles (see Figure 10b).

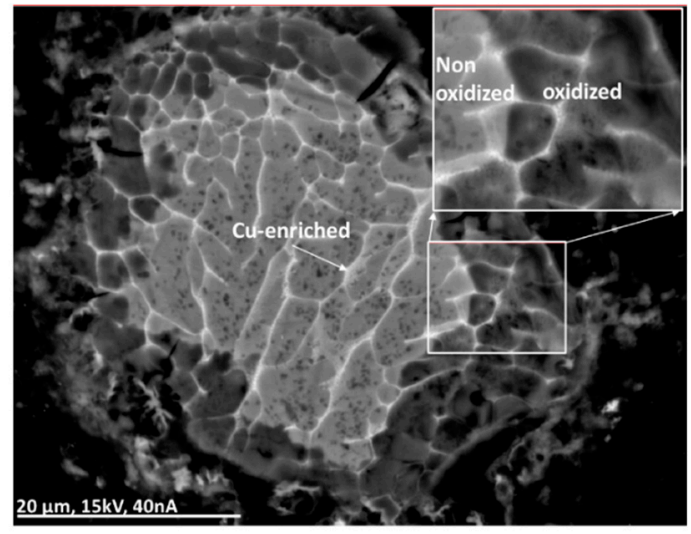

(a)

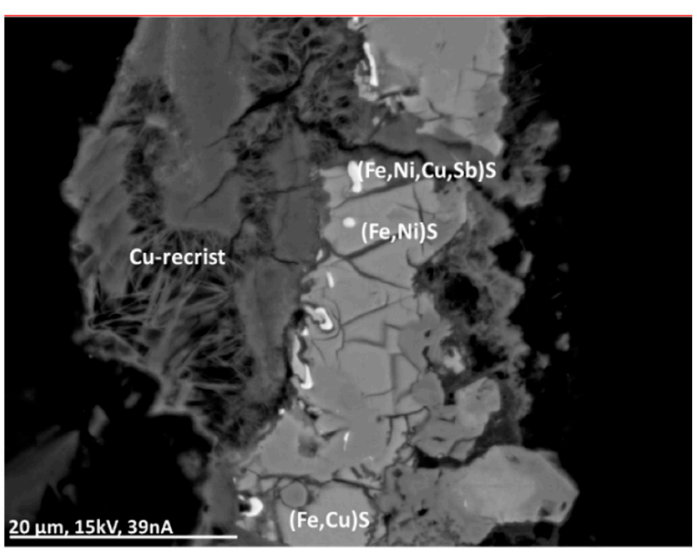

(b)

Figure 10. $\mathrm{BSE}(\mathrm{Z})$ micrographs of alteration in a partly $\mathrm{Cu}$-enriched Al-alloy particle (a) and a complex sulfide particle including recrystallization (b). For explanation, see text.

Additionally, particles rich in sulfides containing $\mathrm{Ni}$ and $\mathrm{Cu}$ (or $\mathrm{Sb}$ ) can be surrounded partly with crystal whiskers indicating recrystallization processes (Figure 10b). The crystal whiskers, in this case, contain $\mathrm{Fe}, \mathrm{Ni}$, and $\mathrm{Cu}$ together with $\mathrm{Ca}, \mathrm{S}$, and $\mathrm{Cl}$.

\section{Discussion}

\subsection{Mineralogy and Chemistry}

MSWI-BA results from a highly variable input material and a fast combustion process. Because the ashes do not reach a thermodynamic equilibrium, the phase composition cannot be compared with long-term natural phase-forming processes. Therefore, an unusual mixture of artificial and naturally occurring mineral compounds and particles, resulting from various technical products from private and industrial sources (electric devices, packaging materials, etc.) is to be expected. Because of the presence of $\mathrm{Si}$ in many industrial products as well as natural minerals, various types of glass or secondary silicates can be determined. Furthermore, the ash contains oxygen-free particles resulting from melt reactions during combustion, as well as from primary materials (circuits, plating, packaging material, etc.).

Differentiating whether the alloy particles are primary (e.g., splinters from electric devices) or secondary (molten droplets resulting from combustion) is not straightforward. One indication could be the particle shape. The overview micrograph of Figure 6a shows round-shaped particles of relatively pure $\mathrm{Fe}$ accompanied by ragged shaped splinter-like particles of ferroalloy with $\mathrm{Cr}, \mathrm{Mn}, \mathrm{Fe}$, and $\mathrm{Ni}$, indicating that the incineration temperature was only high enough to melt pure Fe.

Many of the particles with a partly complex morphology and chemistry cannot result from crushed devices or packaging material (such as aluminum foil and tin cans), but are remnants of the incineration process. This can be aggregates of melt droplets resulting from low-melting materials or alloys. Additionally, new compounds can form.

The element $\mathrm{Cu}$ is enriched in sulfide and oxide particles with segregation lamellae and crystal whiskers. This is an indication that these mineral compounds have formed during the combustion of the waste material and that the sulfur availability is comparatively high. 
Elemental copper particles resulting from printed circuit boards and the like were not found within the analyzed particle size fraction. This implies that $\mathrm{Cu}$ occurs in compounds that are not stable under the conditions of the combustion.

The samples taken at several points in the RENE-adapt process showed only slight differences in their chemical and mineralogical composition. The only remarkable difference is that, in the magnetic fractions (the samples direct mag and stored mag), the iron content is higher and more splinters of iron can be observed. Even the comparison between the processed and the unprocessed samples shows no higher differences.

The investigation of ash after outside storage shows that alteration (oxidation) takes place. Therefore, many of the sulfide particles are surrounded by an oxide layer. In aluminum-containing alloy particles, oxidation frontiers can be observed, indicating that these particles are transformed into oxide relatively fast. Therefore, it is to be expected that, in this case, the particles can be inactivated through oxide layers or frontiers that could render a flotation optimized for sulfides or metals inefficient.

\subsection{Waste Incineration Process}

The results of the mineral characterization allow some conclusions regarding the waste incineration process. As expected, metallic elements are often oxidized due to the incineration. Smaller particles can be completely oxidized, whereas larger particles show oxide layers. One source for fine-grained metal oxides might be brittle oxide layers which are removed due to thermal and mechanical stress during transportation and cooling.

The presence of copper sulfide indicates that the burnout on the grade during the waste incineration is not complete. There must be zones of different temperature and redox conditions. In most incineration plants, the oxygen flow is controlled by the $\mathrm{CO}$ content in the flue gas. This means that zones where no combustion takes place cannot be detected. The primary source for the sulfur might be organic waste and inorganic sulfates-e.g., gypsum. With a sulfur content of $0.1 \%$ to $0.5 \%$ (see Table 1 ), the occurrence of sulfurization in the waste is plausible. The direct entry of the sulfides with the waste is unlikely, because there is no significant application of copper sulfide that explains an initial presence before processing.

The observation of melted iron droplets indicates that the temperature during the incineration exceeds $850^{\circ} \mathrm{C}$ in some parts of the device by far. In contrast, during the first steps of the processing of the MSWI-BA, unburned material (e.g., paper) is removed and delivered back to the incineration plant. This indicates a very uneven temperature distribution over the grate.

\subsection{Processing}

The fact that copper is found in significant amounts bound to oxides and sulfides in the fine-grained fractions shows that a mechanical treatment by eddy current separation or selective crushing is unsuitable for recovery. To regain the copper from the fine fractions, other processing technologies must be applied. Due to the small particle size, only wet processing techniques are applicable.

The particle size analyses showed that the material is very fine-about $40 \%$ of the material is below $20 \mu \mathrm{m}$. Additionally, the finest fractions have a significant copper content. Therefore, a classification before further processing would lead to a significant loss of copper.

Density separation is a technique that is widely used in the processing of primary raw materials as well in the field of recycling. The two most important factors for density separation are the density difference in the materials that should be separated and the particle size. Generally, a smaller particle size requires a greater difference in density for an efficient separation. Table 6 shows the density of the gangue material of the MSWI-BA determined by the XRD analysis and the main copper-bearing phases. The copper phases have all a higher density compared to the gangue phases. However, the minimum density difference of the gangue phases and the copper phases is only $1.62 \mathrm{~g} / \mathrm{cm}^{3}$, which is insufficient for an efficient separation of this particle size [28]. A pre-enrichment by density separation could be 
considered, but is not promising because of the high amount of the fine fraction of the material below $50 \mu \mathrm{m}[2,28]$.

Table 6. Density of the main phases and copper-bearing phases of the MSWI-BA.

\begin{tabular}{ccc}
\hline Phase & Formula & Density in $\mathbf{g} / \mathbf{c m}^{\mathbf{3}}$ \\
\hline Calcite & $\mathrm{CaCO}_{3}$ & 1.7102 \\
Ettringite & $\mathrm{Ca}_{6} \mathrm{Al}_{2}\left[(\mathrm{OH})_{12} \mid\left(\mathrm{SO}_{4}\right)_{3}\right] \cdot 26 \mathrm{H}_{2} \mathrm{O}$ & 1.77 \\
Gypsum & $\mathrm{CaSO}_{4} \cdot 2 \mathrm{H}_{2} \mathrm{O}$ & 2.322 \\
Glass & & 2.5 \\
Quartz & $\mathrm{SiO}_{2}$ & 2.66 \\
Anhydrite & $\mathrm{CaSO}_{4}$ & 2.98 \\
Tenorite & $\mathrm{CuO}$ & 6.45 \\
Covellite & $\mathrm{CuS}$ & 4.6 \\
Cuprite & $\mathrm{Cu}_{2} \mathrm{O}$ & 6.14 \\
Copper & $\mathrm{Cu}$ & 8.92 \\
\hline
\end{tabular}

Magnetic separation, which is also widely used, can deal with much smaller particle sizes than density separation can. In theory, it can be applied down to $5 \mu \mathrm{m}$. To reach such low particle sizes, significant differences in magnetic susceptibility are needed. Due to the very high complexity of the MSWI-BA, it seems unlikely that a reasonable enrichment of copper can be achieved by magnetic separation. The magnetic separation can be considered if a high iron content interferes with the following processing steps [2,28].

The most promising technology seems to be flotation, due to its ability to treat fine-grained materials and the possibility of influencing the surface properties of the particles by chemicals.

The copper(II)-sulfide, copper(II)-oxide, and copper(I)-oxide found in the MSWI-BA also occur in natural ores as covellite $(\mathrm{CuS})$, tenorite $(\mathrm{CuO})$, and cuprite $\left(\mathrm{Cu}_{2} \mathrm{O}\right)$. Covellite is one of the most important copper minerals from an economic point of view, and therefore its flotation properties are well known [29].

On the other hand, tenorite and cuprite are of lower economic importance in primary raw material valorization, and their floatability is less investigated. It is known that both minerals show similar flotation behavior, which differs from other that of typical copper minerals such as malachite. Previous investigations revealed that the flotation of cuprite is possible after sulfidization with anionic collectors. In various studies, sulfidization, together with xanthate type collectors, showed good results [30].

Flotation experiments using cuprite-bearing oxide copper-gold ore from Igrape Bahia (Brazil) showed good results with a phosphine ester-modified xanthate as a collector and sodium sulfide as a sulfidization reagent. For the depression for iron oxide and hydroxide slimes, a polyacrylic-modified starch was used [29]. In other investigations, good results for a cuprite ore are achieved with sodium iso-amyl xanthate as a collector, sodium sulfide as a sulfidization agent, and ammonium sulfate as a dispersant [31].

Due to the high complexity of the MSWI-BA, it seems unlikely that a sulfidization would lead to high-quality concentrates due to its low selectivity. A better solution might be to use collectors optimized for copper oxide. There is a wide range of commercial collectors for natural oxide copper ores [32]. Previous screening investigations with some of these collectors showed promising results [27]. However, further investigations are necessary.

Even if the experiences with collectors for natural cuprite ores can be adapted to MSWI-BA, intensive research on depressants might be needed. Because of the high contents of various elements, the matrix of MSWI-BA is more complex than that of most natural ores of economic interest. Many natural or artificially generated phases might float together with the copper phases or interfere with the collector. For example, the high iron contents might lower the quality of the flotation product. 
Besides copper, noble metals such as silver are present in the MSWI-BA. Even small amounts of gold-for example, from circuit boards - can occur. The flotation properties of the noble metals are quite similar, so it might be possible to enrich them together with the copper phases and recover them together [32].

The process of flotation gets more challenging with decreasing particle sizes. In particular, the flotation of particles below $10 \mu \mathrm{m}$ is still a subject of research. Therefore, desliming is often applied in industrial processes. In the case of MSWI-BA, this would lead to significant copper losses due to the large share of fines (see Figures 2 and 3) [28,33].

\section{Conclusions and Outlook}

The investigation presented in this paper showed relatively stable and similar bulk chemistry as well as mineralogical composition in all the investigated samples. The changes over time are smaller than expected, but it has to be considered that the samples originate from one processing plant which homogenizes large amounts of MSWI-BA from a wide catchment area.

In all samples, the copper content of the fine fractions of MSWI-BA shows concentrations around $0.3 \%$ and thus is comparable to low-grade ores. Copper oxides and copper sulfides are the main copper phases that could be identified. In the case of outside storage over several weeks, the sulfide particles showed an oxide layer, which means that, during flotation, they would mostly behave like copper oxide particles. In the actual investigations, no particles of pure elemental copper could be observed in the fine-grained samples. While the flotation of copper sulfides is well-investigated and established, the flotation of copper oxides is still under research. In particular, the complex matrix complicates the production of high-grade copper concentrates. Besides copper, zinc may be an element of economic interest.

Many particles show indications of formation during the waste incineration process. Due to the fast incineration process, many phases in the MSWI-BA have not been generated under thermodynamic equilibrium. Besides mineral phases that are similar or identical to natural phases, also phases with no natural equivalent were observed. Molten iron particles and the observation of sulfide particles indicate that the conditions during the incineration process are not consistent in the temperature and redox conditions.

Due the physical properties, flotation seems to be the most promising technology to enrich copper. To concentrate the copper by flotation, the flotation properties of the identified copper oxides have to be investigated in more detail. Due to the oxide layer on the surface of the copper sulfide particles, they probably behave like oxide particles during flotation. For this reason, in the next step of the project a single mineral flotation test will be conducted with copper oxides and sulfides. For this, a hallimond tube will be used. In addition to the flotation tests, the contact angles and sorption isotherms for different combinations of collectors and copper minerals will be measured and evaluated.

After the identification of suitable collectors by flotation tests with simplified synthetic and real MSWI-BA, investigations will be conducted to study the behavior of the matrix in more detail, with a special focus on the usage of depressants.

Author Contributions: T.E. conceived the paper. S.K. and T.S. conducted the literature review. The sample collection and preparation were conducted by S.K. The chemical analysis was executed by the analysis laboratory of the institute and interpreted by S.K. The phase analysis was run and interpreted by T.S. S.K., T.S, and D.G. wrote the paper. The project was acquiesced by T.E. The project is supervised by T.E. and D.G. D.G. developed the strategic setting for this project within the research field of engineering of artificial minerals. All authors have read and agreed to the published version of the manuscript.

Funding: This research was funded by Deutsche Forschungsgemeinschaft (DFG), grant number 403179546.

Acknowledgments: The authors would like to express their gratitude to the DFG for the financial support. Furthermore, the authors are grateful to the Strabag AG for providing the sample material. We would also like to show our gratitude to the analytic laboratory of the institute for the collaboration. We acknowledge support by the Open Access Publishing Fund of Clausthal University of Technology. 
Conflicts of Interest: The authors declare no conflict of interest. The funding organization had no role in the design of the study; in the collection, analysis, or interpretation of data; in the writing of the manuscript; or in the decision to publish the results.

\section{References}

1. State-of-the-art for practitioners, analysts, and scientists. In Handbook of Recycling; Worrell, E.; Reuter, M.A. Eds.; Elsevier: Amsterdam, The Netherlands, 2014; ISBN 978-0-12-396459-5.

2. Schubert, H. Handbuch der Mechanischen Verfahrenstechnik; John Wiley \& Sons: Hoboken, NJ, USA, 2012; ISBN 9783527305773.

3. Deike, R.; Ebert, D.; Warnecke, R.; Vogell, M. Abschlussbericht zum Projekt „Recyclingpotenziale bei Rückständen aus der Müllverbrennung“. Available online: https://www.itad.de/wissen/studien/20130110_ deike-hmvarecyclingpotentialabschlussbericht.pdf (accessed on 30 March 2020).

4. Wei, Y.; Shimaoka, T.; Saffarzadeh, A.; Takahashi, F. Mineralogical characterization of municipal solid waste incineration bottom ash with an emphasis on heavy metal-bearing phases. J. Hazard. Mater. 2011, 187, 534-543. [CrossRef] [PubMed]

5. Speiser, C. Exothermer Stoffumsatz in MVA-Schlackedeponien: Mineralogische und geochemische Charakterisierung von Müllverbrennungsschlacken, Stoff-und Wärmebilanz. Ph.D. Thesis, Technische Universität München, München, Germany, 2001.

6. Elwert, T.; Goldmann, D.-I.D.; Schirmer, T.; Strauß, K. Affinity of Rare Earth Elements to Silico-Phosphate Phases in the System Al2O3-CaO-MgO-P2O5-SiO2. Chem. Ing. Tech. 2014, 86, 840-847. [CrossRef]

7. Elwert, T.; Goldmann, D.; Schirmer, T.; Strauß, K. Phase composition of high lithium slags from the recycling of lithium ion batteries. Erzmetall 2012, 163-171.

8. Friedrich, B.; Zander, M.; Kemper, C. Rückgewinnung von kupfer und kobalt aus schmelzflüssigen schlacken der ne-metallurgie. In Aschen, Schlacken, Stäube: Aus Abfallverbrennung und Metallurgie; Karl, J., Thomé-Kozmiensky, Eds.; Thomé-Kozmiensky Verlag GmbH: Neuruppin, Germany, 2013; pp. 599-614.

9. Panda, S.; Mishra, S.; Rao, D.S.; Pradhan, N.; Mohapatra, U.; Angadi, S.; Mishra, B.K. Extraction of copper from copper slag: Mineralogical insights, physical beneficiation and bioleaching studies. Korean J. Chem. Eng. 2015, 32, 667-676. [CrossRef]

10. Potysz, A.; van Hullebusch, E.D.; Kierczak, J.; Grybos, M.; Lens, P.N.L.; Guibaud, G. Copper Metallurgical Slags-Current Knowledge and Fate: A Review. Crit. Rev. Environ. Sci. Technol. 2015, 45, 2424-2488. [CrossRef]

11. Schlumberger, S.; Bühlrt, J. Metallrückgewinnung aus filterstäuben. In Aschen, Schlacken, Stäube: Aus Abfallverbrennung und Metallurgie; Thomé-Kozmiensky, Ed.; Thomé-Kozmiensky Verlag GmbH: Neuruppin, Germany, 2013; pp. 377-396, ISBN 978-3-935317-99-3.

12. Brett, B.; Schrader, D.; Räuchle, K.; Heide, G.; Bertau, M. Wertstoffgewinnung aus Kraftwerksaschen Teil I: Charakterisierung von Braunkohlenkraftwerksaschen zur Gewinnung strategischer Metalle. Chem. Ing. Tech. 2015, 87, 1383-1391. [CrossRef]

13. Martens, H.; Goldmann, D. Recyclingtechnik; Springer Fachmedien Wiesbaden: Wiesbaden, Germany, 2016; ISBN 978-3-658-02785-8.

14. Huyen, P.T.; Dang, T.D.; Tung, M.T.; Huyen, N.T.T.; Green, T.A.; Roy, S. Electrochemical copper recovery from galvanic sludge. Hydrometallurgy 2016, 164, 295-303. [CrossRef]

15. Pikhard, O.; Pretz, T. Schleifschlamm Quo vadis. Müll und ABfall 2009, 398-405. [CrossRef]

16. Breitenstein, B. Verfahren zur Rückgewinnung von NE-Metallen aus feinkörnigen Rostaschen der thermischen Abfallbehandlung. Ph.D. Thesis, Technische Unversität Clausthal, Clausthal, Germany, 2017.

17. Neuwahl, F.; Cusano, G.; Benavides, J.G.; Holbrook, S.; Roudler, S. Best Available Techniques (BAT) Reference Document for Waste Incineration. Available online: http://eippcb.jrc.ec.europa.eu/sites/default/files/2020-01/ JRC118637_WI_Bref_2019_published_0.pdf (accessed on 6 February 2020).

18. Siebzehnte Verordnung zur Durchführung des Bundes-Immissionsschutzgesetzes. 17. BImSchV. Available online: https://www.gesetze-im-internet.de/bimschv_17_2013/BJNR104400013.html (accessed on 2 May 2013).

19. Syc, M.; Simon, F.-G.; Biganzolli, L.; Grosso, M.; Hyks, J. Recource Recorvery from Incineration Bottom Ash: Basics, Concepts, Principles. In Removal, Treatment and Utilisation of Waste Incineration Bottom Ash; Holm, O., Ed.; Thomé-Kozmiensky Verlag GmbH: Neuruppin, Germany, 2018; pp. 1-9, ISBN 978-3-944310-44-2. 
20. Bunge, R. Recovery of Metals from Waste Incinerator Bottom Ash. Available online: https://www. umtec.ch/fileadmin/user_upload/umtec.hsr.ch/Dokumente/Metals_from_MWIBA_6_2019.pdf (accessed on 6 February 2020).

21. Alba, N.; Gassó, S.; Lacorte, T.; Baldasano, J.M. Characterization of Municipal Solid Waste Incineration Residues From Facilities with Different Air Pollution Control Systems. J. Air Waste Manag. Assoc. 1997, 47, 1170-1179. [CrossRef]

22. Seifert, S.; Thome, V.; Karlstetter, C.; Maier, M. Elektrodynamische fragmentierung von mva-schlacken: Zerlegung der schlacken und abscheidung von chloriden und sulfaten. In Aschen, Schlacken, Stäube: Aus Abfallverbrennung und Metallurgie; Thomé-Kozmiensky Verlag GmbH: Neuruppin, Germany, 2013; pp. 353-365, ISBN 978-3-935317-99-3.

23. Alwast, H.; Riemann, A. Verbesserung der Umweltrelevanten Qualitäten von Schlacken aus Abfallverbrennungsanlagen. Available online: http://www.uba.de/uba-info-medien/4025.html (accessed on 6 February 2020).

24. Bayuseno, A.P.; Schmahl, W.W. Understanding the chemical and mineralogical properties of the inorganic portion of MSWI bottom ash. Waste Manag. 2010, 30, 1509-1520. [CrossRef] [PubMed]

25. Böni, D.; Morf, L. Thermo-Recycling: Efficient Recovery of Valuable Materials from Dry Bottom Ash. In Removal, Treatment and Utilisation of Waste Incineration Bottom Ash; Holm, O., Ed.; Thomé-Kozmiensky Verlag GmbH: Neuruppin, Germany, 2018; pp. 25-37, ISBN 978-3-944310-44-2.

26. Stockinger, G. Direct Wet Treatment of Fresh, Wet-Discharged Grate Ash from a Waste Incineration Plant. In Removal, Treatment and Utilisation of Waste Incineration Bottom Ash; Holm, O., Ed.; Thomé-Kozmiensky Verlag GmbH: Neuruppin, Germany, 2018; pp. 47-52, ISBN 978-3-944310-44-2.

27. Breitenstein, B.; Elwert, T.; Goldmann, D.; Haas, A.; Schirmer, T.; Vogt, V. Froth Flotation of Copper and Copper Compounds from Fine Fractions of Waste Incineration Bottom Ashes. Chem. Ing. Tech. 2017, 89, 97-107. [CrossRef]

28. Wills, B.A.; Finch, J.A. Wills' Mineral Processing Technology; Elsevier: Amsterdam, The Netherlands, 2016; ISBN 9780080970530.

29. Bulatovic, S.M. Flotation of industrial minerals. In Handbook of Flotation Reagents. Chemistry, Theory and Practice; Elsevier: Kidlington, UK, 2015; Volume 3, ISBN 978-0-444-53083-7.

30. Bulatovic, S.M. Handbook of Flotation Reagents. Chemistry, Theory and Practice, 1st ed.; Elsevier: Amsterdam, The Netherlands, 2010; ISBN 978-0-444-53082-0.

31. Xiong, K.; Wen, S.M.; Zheng, G.S.; Bai, S.J.; Shen, H.Y. Flotation Research on Cuprite-Type Oxide Copper in XinJiang. AMR 2012, 524-527, 987-992. [CrossRef]

32. Cytec Industries Inc. Mining Chemicals Handbook; Arnold, D., Ed.; CYTEC: Woodland Park, NJ, USA, 2010.

33. Farrokhpay, S.; Filippov, L.; Fornasiero, D. Flotation of Fine Particles: A Review. Miner. Process. Extr. Metall. Rev. 2020, 31, 1-11. [CrossRef]

(C) 2020 by the authors. Licensee MDPI, Basel, Switzerland. This article is an open access article distributed under the terms and conditions of the Creative Commons Attribution (CC BY) license (http://creativecommons.org/licenses/by/4.0/). 